\title{
A new version of the reliance theory
}

Peter Jaffey

* Lecturer, Brunel University. A version of this paper was presented at the SPTL Conference in September 1997. I am grateful to Tony Jaffey, James Penner and Steve Smith for their suggestions.

\section{INTRODUCTION}

In contract law, a crude distinction can be drawn between the classical theory and the reliance theory. The main features of the classical theory seem to be freedom of contract, the bargain theory of consideration, and the expectation measure of damages, and those of the reliance theory limited freedom of contract, an expansion of contract to include cases of detrimental reliance not arising out of an agreement or bargain, and the reliance measure of damages. On one view, the reliance theory is tantamount to the reduction of contract into tort and restitution and the rejection of a distinct law of contract. However it has never been made clear exactly how to characterise the classical theory and the reliance theory.

In this article, I will offer an interpretation of the classical theory and the reliance theory, but not one that reflects entirely the main features mentioned above. The classical and reliance theories will be understood as follows. Under the classical theory, contract law is based on promising. To promise is to assume an obligation to the promisee by means of a communication to the promisee to that effect. ${ }^{1}$ An agreement is taken to entail the making of a promise in return for a promise (or for performance), and if an agreement is recognised as a contract in law, the law recognises a contracting party as having incurred a legal obligation to perform his promise. Under the reliance theory, an agreement specifies the performance of a contracting party, but that party does not promise the performance and does not incur an obligation to provide it. Contract is not based on promising but on what will be described as the "assumption of responsibility". A contracting party assumes responsibility for reliance incurred by the other party on the assumption that the specified performance will be provided. An assumption of responsibility is, analogously to a promise, the exercise of a normative power through the communication of an intention to assume responsibility. Discussion and judgments in contract law generally presuppose the classical theory; one might say that the rhetoric of contract law is classical. However, as far as the substance is concerned, I will argue that on the whole the reliance theory explains

\footnotetext{
${ }^{1}$ See J Raz, "Promises and Obligations", in Law, Morality \& Society (P Hacker \& J Raz, eds, 1977); US Restatement (Second) of Contracts para 2(1) (1981). I will use "voluntary obligation" to refer to an obligation arising from a promise, although a voluntary obligation can arise in other ways, and similarly "voluntary liability" with respect to assumptions of responsibility as defined below.
} 
the law of contract more convincingly than the classical theory, and provides solutions to important problems in the law of contract. I will also distinguish this version of the reliance theory from other versions, including the "death of contract" thesis, and show how it is not open to the criticisms made of them. ${ }^{2}$

After an explanation of the rationale of this version of the reliance theory, I will discuss the classical and reliance theories in relation to various aspects of contract law, including the overlap with tort and restitution. In a brief final section I will consider one or two more fundamental issues concerning the reliance theory that are touched upon elsewhere in the article.

\section{The reliance theory and the "assumption of responsibility"}

People have an interest in exchanging benefits, and in particular exchanging a benefit for payment. Typically one party (the "recipient") will receive a benefit in the form of a good or service and the other (the "supplier") will receive a benefit in the form of payment to compensate him for his expenses and remunerate him for his work (or provide a return on his investment). Generally such exchanges will not take effect without a prior (or simultaneous) agreement; in the absence of an agreement it will not generally be fair to expect the recipient to pay for anything he has received, nor practicable to assess the appropriate payment. ${ }^{3}$ Such an agreement should be legally enforceable, so that the parties can feel secure in proceeding with performance where, as is usually the case, this involves some work or expenditure or opportunity cost before anything is received in return. It is the role of contract law to give effect to agreements. The classical theory of contract presumes that the agreement consists of an exchange of promises - generally a promise to provide a benefit and a promise to pay for it - which generate obligations in law to provide the benefit and to pay for it. But the exchange of benefits can equally take effect under an agreement consisting of assumptions of responsibility rather than the exchange of promises.

In an agreement as interpreted under the "assumption of responsibility" version of the reliance theory, the parties do not say, as the classical theory envisages, "I promise to do this, and you promise to do that", but "We will proceed on the assumption that I am to do this and you are to do that, and, although I do not promise that I will do this, I accept responsibility for your reliance on the assumption that I will, and you will accept responsibility for my reliance in the same way." The effect of an

\footnotetext{
${ }^{2}$ The reliance theory is associated with, amongst others, LL Fuller \& WS Perdue, "The reliance interest in contract damages" (1936) 46 Yale LJ 52; PS Atiyah, Essays on Contract (1986), Promises, Morals, and Law (Oxford, 1981), The Rise and Fall of Freedom of Contract (Oxford, 1979); G Gilmore, The Death of Contract (Ohio State University Press 1974); J Raz, "Promises in morality and law" (1982) 95 Harv LR 916; H Collins, The Law of Contract (Butterworths, 3rd ed 1997).

${ }^{3}$ Falcke $v$ Scottish Imperial Insurance (1886) $34 \mathrm{Ch}$ D 234 is taken to be authority for the general rule that no liability arises for an uncontracted-for benefit.
} 
assumption of responsibility is to subject the contracting party to a contingent liability to satisfy the reliance interest (in the sense defined below), but not a duty to carry out the performance specified in the contract. ${ }^{4}$ In this way each party will proceed with the exchange of benefits as envisaged, with the reassurance not that the performance he expects is his legal entitlement by virtue of an obligation owed to him, but that at least he will not lose out as a result of embarking on the exchange. This type of arrangement may not provide as much security as an agreement that generates an entitlement to the contracted-for benefit, because there will inevitably be problems of measurement of the consequences of reliance. But it has the advantage that it is less burdensome in constraining the parties' behaviour and leaves them the option of abandoning performance subject to a liability to satisfy the other's reliance interest. It is plausible that a party who is to provide goods or services for payment is likely to prefer an arrangement that does not bind him to perform but leaves him the option to do something else subject only to a liability to satisfy the reliance interest. ${ }^{5}$ A party who is to receive work or goods might ideally prefer the security of an obligation of performance, but it is plausible that he will accept an arrangement that protects his reliance on the contract if this is what the other party prefers and under it he will offer a lower price. ${ }^{6}$

\section{REMEDIES}

\section{Damages}

\section{The classical theory}

The appropriate measure of damages to protect the interest of a promisee under the classical theory is clear in principle. As Professor Friedmann has recently explained, the expectation measure of damages clearly follows from the very recognition of a contractual obligation. ${ }^{7}$ If the law recognises that by

\footnotetext{
${ }^{4}$ It is better to refer to a contingent liability rather than a contingent obligation, because an obligation denotes what ought to be done and a liability (in this context) represents a sum owing and can be distinguished from the obligation to pay it.

${ }^{5}$ Even if this means that he will receive only payment for what he does, and does not have any prospect of obtaining his net profit on the contract without having to do the work (as may happen under the classical theory).

${ }^{6}$ The theory of economic breach also postulates the absence of a duty of performance, although it is perversely expressed in terms of a right or freedom to breach a duty of performance. For a critique based on this contradiction see D Friedmann, "The Efficient Breach Fallacy" (1989) 18 Journal of Legal Studies 1. The theory of efficient breach purports to explain the freedom of a contracting party not to perform in terms of wealth maximisation: eg Posner, Economic Analysis of Law (Little, Brown, 4th ed 1992), 117-119. By contrast, the argument here is that the freedom not to perform follows from what the parties have agreed. They reach this agreement because they judge that this best serves their interests, and consequently (since generally only their interests are at stake) it will also generally be wealth-maximising. But the justification for recognising a freedom not to perform is simply the agreement, not that it is wealth-maximising. Thus efficiency arguments have no justificatory relevance, although they may be of assistance in judging what the parties have agreed, or, with respect to implied terms, what they would have agreed.

${ }^{7}$ Daniel Friedmann, "The Performance Interest in Contract Damages" [1995] LQR 628; Charles Fried, Contract as Promise (1981, Harvard University Press) 17-21; see also Ernest J Weinrib “The Juridical Classification of Obligations" in P Birks, ed, The Classification of Obligations (OUP, 1997).
} 
virtue of a legally binding contract the promisor has incurred an obligation to provide a specified performance to the promisee, the promisee must be entitled to the value of the performance, less the saving of the cost of his own performance - which means the expectation measure - if he does not receive the performance itself. This can be described as the simulation principle, i.e., the principle that the function of the remedy is to simulate the performance by conferring its equivalent in pecuniary damages. This corresponds of course to the normal remedy for breach of contract recognised by the courts. $^{8}$

The contractual expectation measure is usually contrasted with the tortious measure, but, as Friedmann points out, there is really no difference in principle between the assessment of damages in contract and tort. ${ }^{9}$ Both apply the simulation principle, and the difference lies in the nature of the obligation. In tort law, damages simulate compliance by the defendant with the obligation that he breached to avoid harm to the plaintiff by compelling him to pay an amount representing the cost of the harm to the plaintiff, whereas in contract they simulate the breach of an obligation to confer a benefit by requiring payment of the value of the benefit. ${ }^{10}$

\section{The measure of damages under the reliance theory}

The appropriate measure of damages under the reliance theory - the amount necessary to satisfy the reliance interest - is not as straightforward in principle. This is so because generally it is the sum necessary to put the plaintiff in the position he would have been in if he had not entered the contract, and this may be a matter of conjecture. It can relate to opportunity cost or work done or sums expended. ${ }^{11}$ It is usually regarded as a major obstacle to the reliance theory that it is the expectation measure that is the normal measure of damages in contract law. However it is reasonably clear, first, that the appropriate measure of damages to satisfy the reliance interest should not exceed the expectation measure. ${ }^{12}$ A party will not embark on a contract unless he considers at the time of the contract that the value to him of the contract will at least equal whatever other benefit he may otherwise

\footnotetext{
${ }^{8}$ British Westinghouse Electric v Underground Electric Railways [1912] AC 73

${ }^{9}$ Friedmann, op cit at n 7, 638-43. See also JE Penner, "Voluntary Obligations and the Scope of the Law of Contract" (1996) 2 Legal Theory 325.

${ }^{10}$ It has sometimes been suggested that tort law does protect expectations, for example in the form of lost earnings or damage to prospects: see e.g. K Barker "Are we up to expectations? Solicitors, beneficiaries and the tort/contract divide" (1994) 14 OJLS 137, 146-7. This is true, but betrays a misunderstanding of "expectation loss" in contract, which is used (maybe inaptly) to mean a loss in the form of a shortfall in a benefit due from the defendant to the plaintiff. See also J. Stapledon, "The Normal Expectancies Measure in Tort Damages" (1997) 113 LQR 257, 259.

11 Anglia TV v Reed [1972] 1 QB 60 is an example of a claim for expenditure.

${ }^{12}$ Consistently with $C \&$ P Haulage v Middleton [1983] 1 WLR 1461 and CCC Films (London) Ltd v Impact Quadrant Films [1985] QB 16.
} 
obtain (his opportunity cost). ${ }^{13}$ This means that putting the plaintiff in the position he would have been in if the contract had been performed will necessarily ensure the satisfaction of his reliance interest, as valued by him at the time of the agreement. At the same time, from the defendant's point of view, limiting the claim to the expectation measure means that the defendant's liability cannot exceed the cost to the defendant of his own specified performance. Of course the agreement, and the implicit valuation of the plaintiff's reliance interest with the expectation measure, is made before the parties know for sure how much expenditure or expertise or effort is necessary, or what the opportunity cost may turn out to have been, and so the plaintiff's loss may in fact turn out to exceed the expectation measure. Nevertheless limiting the claim to the expectation measure is appropriate because its effect is to allocate risk with respect to factors affecting the cost and value of performance that are unknown or difficult to judge at the time of contracting or change subsequently. ${ }^{14}$ The supplier takes the risk of changes in the cost of providing the benefit sought by the recipient or the value to him of the necessary work, and the recipient takes the risk that, as things turned out, he might have spent his time and money in a way that was more valuable to him. Holding the parties to the valuation gives effect to the agreement and is generally fair because it was the basis on which the parties incurred reliance or assumed responsibility for it. ${ }^{15}$

It is maybe more difficult to show that the expectation measure is not excessive as a means of satisfying the reliance interest. Whenever a party embarks on a contract, he might have chosen to do something else, and this other option (whose value to him is the opportunity cost of the contract) might have been only marginally less valuable to him than the contract he made - in other words, it may be that the plaintiff would not have entered the contract if the benefit offered by the defendant had been any less than it actually was. In the case of a competitive market, this will generally be the case. In such a case the expectation measure is apt as a measure of what is necessary to satisfy the reliance interest. But even in other cases, where there was no other equivalent benefit available, it may nevertheless be the case that the plaintiff's opportunity cost approximated to the value of the contract to him, by virtue of a quite different alternative benefit, but here it will be extremely difficult for the plaintiff to establish

\footnotetext{
${ }^{13}$ Or, as considered below, in the case of a supplier, the sum of his own costs and the minimum he is prepared to be paid in addition for his work if this exceeds the opportunity cost.

${ }^{14}$ See Fuller \& Purdue, op cit at n2, at 79. In the same way the exchange of promises allocates risk under the classical theory.

${ }^{15}$ Aside from issues of exploitation or mistake or a jurisdiction to upset grossly unfair contracts. Limiting the plaintiff to the expectation measure by virtue of the contractual valuation is quite different from saying that the plaintiff is limited to his reasonable reliance loss, and that loss incurred in reliance on the assumption that the defendant will provide a specified performance cannot be reasonable if it exceeds the value of the performance. It is quite possible that the plaintiff might act reasonably in reliance and then discover that his expenditure in reliance, or his opportunity cost from performing this contract rather than another one, exceeds the value of the benefit he was due to receive from the defendant. The contractual valuation in this sense is also quite different from saying that the benefits obtained by the two parties under the contract are equal, which is implausible.
} 
the fact. ${ }^{16}$ Given that the defendant assumed responsibility for the plaintiff's reliance loss, he should not be able to take advantage of this difficulty, and so arguably the expectation measure should be awarded because it gives the plaintiff the benefit of the doubt and relieves him of the need to prove his actual reliance loss. ${ }^{17}$

Furthermore, the plaintiff may well have incurred just as much reliance loss when the contract breaks down early as when it breaks down towards completion. As soon as he has begun to rely on the contract, he may already have given up an alternative contract. Thus, even if the contract breaks down early on, the plaintiff needs to receive the expectation measure if the difficulty of proving reliance loss is resolved in his favour. Although in principle the contract should not be of any effect until there has been actual reliance, because of the difficulty of determining whether reliance (for example an opportunity cost) has yet occurred, it is reasonable that a court should assume that there has been reliance once the contract has been made. In reality it may sometimes be clear to the parties, if not to the court, particularly in the case of early termination, that the expectation measure is liable to be excessive as a measure of reliance loss. ${ }^{18}$ There is some empirical evidence that business people regard the availability of the full expectation measure in all cases as excessive, and that, at least in the context of a continuing relationship, they do not usually demand it. ${ }^{19}$ This is understandable in the light of the reliance theory, even if the expectation measure remains appropriate where the matter reaches court in order to protect the plaintiff from the difficulty of proof, but it is difficult to understand in the light of the classical theory's interpretation of an agreement.

Where the contract has ended early, the plaintiff may be able to take up alternative contracts or other activities that would have been precluded if the contract had continued to completion. These constitute part of the opportunity cost that make up the reliance interest in respect of his whole contractual performance, and because they are now available to him, their value cannot be included in

\footnotetext{
${ }^{16}$ Thus the opportunity cost argument need not be confined to the case of a competitive market or the "credit system" as suggested by Fuller \& Purdue, op cit at n2, 64.

${ }^{17}$ Friedmann argues (op cit at $\mathrm{n} 7,638$ ) that the plaintiff cannot claim that the benefit he would have obtained from another contract is his opportunity cost because if he is confined to the reliance measure he would not have been entitled to the full benefit from that contract (and similarly with respect to further hypothetical contracts). But so long as contracts are generally performed rather than broken, the opportunity cost of a missed contract approximates to the full benefit that would have been obtained through it, even if recovery is in the reliance measure.

${ }^{18}$ As in Centrovincial Estates v Merchant Investors (1983) Com LR 158. The fact that under the expectation measure the plaintiff receives the net profit for the whole contract and not just for the part of it he has done has been criticised by PS Atiyah "Contract, Promises \& Obligations" in Essays on Contract, (Oxford, 1996), 32ff; and see also Melvin Aron Eisenberg "The Bargain Principle and its Limits" (1992) Harv LR 785-98.

${ }^{19}$ See S Macaulay, "Non-Contractual Relations in Business: A Preliminary Study" (1963) 28 Am Soc Rev 55, 61; H Beale \& A Dugdale (1975) 2 Brit J L\&S 45, 53. Macaulay seems to have inferred, from the disparity between the results in these studies and the prescriptions of the classical theory, that the law is largely or often inconsistent with the parties' understanding of their agreement. This sceptical response is unnecessary under the reliance theory.
} 
his reliance claim, which diminishes accordingly. A plaintiff-recipient may still be able to make a contract to procure exactly the same benefit, so that his reliance loss is nil; similarly a plaintiff-supplier may be able to take up alternative work which will reduce his claim in the expectation measure by the amount he can earn through the work he can now do instead of the contractual performance. This is the effect of the rule of mitigation, which, as considered below, is in certain respects difficult to reconcile with the classical theory.

There may be cases where it is not appropriate to resolve the doubt over the plaintiff's reliance loss in his favour, so that his claim should be limited to actually provable reliance loss. This might be the case where, rather than the defendant having failed to perform in accordance with the contract, the contract has been frustrated. Here either party might have a prima facie claim for his reliance loss, but arguably it would be appropriate to expect the parties to prove actual reliance loss. Similarly it has been argued that in some circumstances a party who has himself failed to perform should have a claim if otherwise the other party would be left better off than if the contract had been performed. Here again the plaintiff should have a reliance claim, but only for provable reliance loss and not in the presumptive expectation measure. $^{20}$

Where the plaintiff has to prove the actual reliance measure, he should be able to claim in respect of work actually done as well as actual expenditure or a proved opportunity cost, even if the work done entailed no provable opportunity cost. Doing work does not in itself entail a loss, although it may entail an opportunity cost; but the satisfaction of the reliance interest should require payment for labour as such, because it is part of the purpose of contract to protect the interest in being paid for labour done in reliance on a contract, irrespective of whether the labour entailed any loss. ${ }^{21}$ Where the plaintiff is permitted the expectation measure as a measure of his opportunity cost, the interest in payment is implicitly protected, because the opportunity cost includes payment for labour that would have been received through another contract. The lesser claim for actual reliance loss will, in the case of a supplier of work and materials, be for a fraction of the price of the work corresponding to the fraction of the total work required for complete performance. This reflects the contractual valuation of the plaintiff's reliance loss in terms of the value to him of the defendant's reciprocal performance. This falls short of the expectation measure (which is the price less the expenditure saved) by the net profit on the work not done. This lesser claim is not unknown to the law: it is the quantum meruit claim for work

\footnotetext{
${ }^{20}$ See under "Restitutionary claims in contract" below.

21 One might argue that the opportunity cost is necessarily the minimum amount the plaintiff would have accepted for the work. But where the plaintiff has done work pursuant an agreement to pay his reliance interest requires payment for the work irrespective of whether he has incurred a loss.
} 
and materials, typified by the old case of Planché $v$ Colburn. ${ }^{22}$ The quantum meruit claim is usually regarded as a non-contractual restitutionary claim, ${ }^{23}$ but this account reveals it clearly as a contractual reliance claim. ${ }^{24}$ The quantum meruit (in this sense) seems to be awarded only exceptionally, where the plaintiff does not get the benefit of the doubt over the measure of his reliance loss. ${ }^{25}$ However the quantum meruit will tend to correspond to the award that the plaintiff is left with where under the mitigation rule his claim is reduced to exclude the net profit he did or could have made from another contract.

\section{The reliance and restoration measures, and the non-contractual quantum meruit}

It is helpful to contrast the reliance measure with what may be called the "restoration measure". ${ }^{26}$ The restoration measure represents the plaintiff's loss from entering the contract, measured independently of the contract (i.e., not in terms of the value of the performance due to him), and excluding any measure of payment for work done. The restoration measure would be the appropriate measure of recovery if the defendant had committed a tort in the making of the contract, for example a misrepresentation, but it cannot be appropriate as a remedy arising from the contract itself because it is inconsistent with the contractual valuation and may exceed the expectation measure. ${ }^{27}$

Also the contractual quantum meruit or reliance claim in respect of work done and expenditure valued in accordance with an agreement should be distinguished from the non-contractual quantum meruit in respect of loss incurred and payment for work done in conferring a benefit measured independently of any contract or in the absence of a contract. The non-contractual quantum meruit is also inappropriate as a remedy arising out of a valid contract, because it is inconsistent with the contractual valuation. It may for example exceed the expectation measure where a contract turns out to have been a

\footnotetext{
22 (1831) Bing 14.

${ }^{23}$ The historical reasons why the quantum meruit is treated as non-contractual are complex. See for example Pavey \& Matthews $v$ Paul (1986) 162 CLR 221; D Ibbetson "History in the High Court of Australia" (1988) 8 OJLS 312. In the modern law the mischaracterisation results from the assumption induced by the classical theory that a breach of contract can generate only an expectation claim representing the cost of the defendant's breach to the plaintiff on the assumption that the plaintiff had an entitlement to performance.

${ }^{24}$ The quantum meruit can also refer to the price for work done awarded where the plaintiff was employed on the basis that he would be paid for what he did rather than by way of a price for a specified performance, where it is consistent with both the classical and the reliance theories.

${ }^{25}$ There is no reason why the plaintiff should prefer the quantum meruit, since, like the reliance claim generally, it must be subject to the "contractual ceiling": this limitation is generally recognised by those who regard it as a non-contractual restitutionary claim: see Goff \& Jones, The Law of Restitution (Sweet \& Maxwell, 4th ed, 1993), 427.

${ }^{26}$ For a discussion that is not based on a reliance theory but uses some similar concepts to those used here, see Eric G Anderson, "The Restoration Interest and Damages for Breach of Contract" (1994) 53 Maryland LR 1.

${ }^{27}$ The restoration measure could include the expenditure incurred, opportunity cost, prepayment, and the cost of undoing work: this appears to be the measure recognised by the courts for misrepresentation.
} 
poor bargain for the plaintiff, because the contract price is insufficient to cover his expenditure and pay him a reasonable rate for his work. In the exceptional case of necessitous intervention it may be appropriate for the plaintiff to be entitled to a non-contractual quantum meruit in respect of a benefit conferred in the absence of a prior agreement to pay for it. ${ }^{28}$

\section{Restitutionary claims in contract}

There are two claims that arise on the termination of contract that are traditionally regarded as restitutionary rather than contractual. The first is the claim for a quantum meruit in respect of work done under a contract. This is incongruous in the classical theory, for which the simulation principle requires the expectation measure. But as suggested above, if the claim is allowed it is explicable as a reliance claim; there is no need to resort to a restitutionary or other non-contractual account. ${ }^{29}$ The explanation under the reliance theory can also account for a claim by a party who himself failed to perform, or by either party on the frustration of the contract. ${ }^{30}$ Such a claim is difficult to explain as a contractual claim under the classical theory because it clearly does not arise from any breach of duty, and the fact that it is or ought to be available to a party in breach or to either party on frustration has been invoked in support of the argument that it must be restitutionary and not contractual. ${ }^{31}$ But under the reliance theory a claim does not arise from a breach of duty, but from an assumption of responsibility for the reliance interest. On frustration, it is reasonable that the parties should incur such liabilities as are necessary to ensure that reliance loss is shared fairly between them. ${ }^{32}$ And even when it was the plaintiff who decided not to perform or failed to perform, it may be appropriate for the defendant, even though he was always willing and able to perform, to satisfy some part of the plaintiff's reliance interest if otherwise the defendant would end up with a surplus beyond what is necessary to satisfy his own reliance loss. ${ }^{33}$

The second is the claim to recover a prepayment in the event of complete failure of consideration. Where the plaintiff has made a prepayment to the defendant, he is entitled to recover the amount of the payment instead of damages in the expectation measure, even if the amount of the

\footnotetext{
28 See P Jaffey, "The Restitutionary Conditional Transfer Theory and the Death of Contract" [1998] Edinburgh LR (forthcoming). For an efficiency argument, see Andrew Kull, "Restitution as a Remedy for Breach of Contract" (1994) $67 \mathrm{~S}$ Calif LR 1465,1472.

${ }^{29}$ For such an approach see for example Goff \& Jones, op cit at n25, 424ff.

${ }^{30}$ For the restitutionary approach, see Goff \& Jones, op cit at n25, 428ff.

${ }^{31}$ P Birks, "Restitution and Freedom of Contract" (1983) 36 CLP 141, 149.

${ }^{32}$ The law on claims arising on frustration under the Law Reform (Frustrated Contracts) Act 1943 is complex and there is no room here to defend the view that this suggestion is consistent with the law as it stands.

${ }^{33}$ It seems that such a claim is not available under English law against a wrongdoer (Sumpter v Hedges [1898] 1 QB 673), but it has been argued that it should be available: Law Commission Report no 121, Pecuniary Restitution on Breach of Contract (1983) para 2.68. See P Jaffey, op cit at n28.
} 
payment is greater, provided that there has been a complete failure of consideration, which is usually understood to mean that the plaintiff has not received any benefit at all under the contract. ${ }^{34}$ This is ostensibly inconsistent with both the classical and reliance theories, because under both theories the expectation measure constitutes a cap on recovery. In fact, as is generally recognised, the claim is not a contractual claim but a restitutionary claim for the reversal of the prepayment. Nevertheless the claim is inconsistent with the existence of a valid contract, even if the contract has terminated. ${ }^{35}$ But the availability of such a restitutionary claim is consistent with the reliance theory, if it is limited to arise only where the defendant has not relied on the contract. Under the reliance theory the contract is in principle effective from the time of reliance, and although there is normally a presumption of reliance from the time of the contract, where the contract has ended as a result of the defendant's nonperformance, it is fair to abandon the presumption and allow the plaintiff to show that the defendant has done nothing in reliance on the contract in order to justify disregarding the contract and allowing the plaintiff to recover the whole of a prepayment in restitution. The restitutionary claim arises on the basis that the payment was made pursuant to an ineffective contract and the defendant cannot invoke the contractual valuation to limit it to the expectation measure. This explains the law on complete failure of consideration if complete failure of consideration is understood to mean complete absence of reliance by the defendant - i.e., that the contract is executory as far as he is concerned. ${ }^{36}$ On the other hand under the classical theory, there is no apparent reason why once the agreement has been made the defendant should not be able to limit his liability to the performance or cost of performance of the agreement, so precluding any restitutionary claim in respect of the prepayment, and if a restitutionary claim is recognised notwithstanding the contract there is also no apparent justification for the traditional limitation of the restitutionary claim to cases of complete failure of consideration.

\section{Specific performance}

Specific performance is not available as a matter of course, but only where "damages are inadequate". ${ }^{37}$ This is hard to understand under the classical theory, for if the defendant is under a legal obligation to render a performance why should he not, as a rule, be ordered to carry it out ${ }^{38}$ ? One might argue that this

\footnotetext{
${ }^{34}$ Giles $v$ Edwards (1797) 7 TR 181.

${ }^{35}$ See P Jaffey, op cit at $\mathrm{n} 28$.

36 This explains Hyundai Heavy Industries v Papadopoulos [1980] 1 WLR 1129, and now Stocznia Gdanska v Latvian Shipping (Feb 1998, HL); P Jaffey, op cit at n28.

${ }^{37}$ Sky Petroleum Ltd v VIP Petroleum Ltd [1974] 1 WLR 576

${ }^{38}$ Some commentators have indeed argued that specific performance should be more widely available: $e . g$. Friedmann, op cit at n7, 629-32; Lionel D Smith "Disgorgement of the Profits of Breach of Contract: Property, Contract and 'Efficient Breach"” (1994-5) 24 Can Bus LJ 121, 135-140.
} 
deficiency is trivial because specific performance is only unavailable where, in the terms of the rule, damages are adequate. But if the plaintiff is entitled to performance, why should it not be left to him to decide whether to claim damages or to insist on specific performance because damages are inadequate? He is after all in the best position to make the judgment. By contrast, under the reliance theory each party assumes a contingent liability to satisfy the reliance interest of the other party rather than a duty to perform the contract; thus no general right to specific performance follows directly from the nature of the agreement. The question will be whether damages are adequate to protect the reliance interest, or whether only specific performance can do so, and this judgment has to be taken by the court because the plaintiff might seek specific performance where it is not really necessary to satisfy his reliance interest.

One might argue that specific performance should be available generally for the same reason as the expectation measure of damages, i.e., to eliminate any doubt over the satisfaction of the reliance interest. But this would amount to treating the defendant as having promised performance, and undermine the distinction between promising and assuming responsibility. The distinction presupposes that responsibility for reliance will not always require actual performance. This is generally so, for where the defendant's performance is obtainable from elsewhere expectation damages in the form of the cost of such performance is a reliable way of satisfying the reliance interest. There may be doubt over the adequacy of the expectation measure where, because there is no-one else who can be paid to take over the defendant's performance, it is difficult to quantify it. ${ }^{39}$ But it may be overgenerous to award specific performance in all such cases. It may be fair to award the expectation measure on the basis of a presumption of reliance loss, but to require a significant identifiable reliance loss in addition to the absence of alternative performance to justify specific performance. For example, where the plaintiff contracted to buy an unusual painting there may be no equivalent performance available, but it might be reasonable to limit the plaintiff to damages, even if difficult to quantify, in the absence of evidence of some particular reliance loss. But there are other cases where there is clearly a significant reliance loss and a stronger argument for specific performance. An example is where the plaintiff has disclosed confidential information to the defendant, which the defendant now threatens to disclose $;^{40}$ another is where the plaintiff has begun a business in reliance on a contract for supplies from the defendant that cannot be obtained from elsewhere, either generally or sufficiently promptly to avoid

\footnotetext{
39 i.e., the defendant's performance is unique. This will include cases where the plaintiff could originally have obtained an equivalent performance, but, the defendant having begun performance, it is not possible for anyone else to take over. These are sometimes described as cases of "bilateral monopoly".

${ }^{40}$ As for example in Snepp v United States 100 S.Ct. 763 (1980), which concerned a claim for disgorgement.
} 
unquantifiable harm to the business; ${ }^{41}$ or where the plaintiff has irrevocably transferred property to the defendant and the defendant accepted a restriction governing his use of the property; ${ }^{42}$ or in certain cases where the defendant's performance is for the benefit of a third party. ${ }^{43}$ In such cases, the plaintiff has effectively become dependent on the defendant, and the refusal by the defendant to perform can be characterised as oppressive. ${ }^{44}$ They are surely the cases where it is most clear that specific performance would be granted. ${ }^{45}$ In such cases, as an exception to the general rule, the assumption of responsibility for the reliance interest generates a duty of performance and concomitantly a right to specific performance. $^{46}$

\section{Withdrawal, termination and mitigation}

Under the classical theory a contracting party has a duty to perform. By the nature of a duty, a party cannot unilaterally renounce it; this would be inconsistent with his being subject to a duty at all. Thus if the defendant has breached or repudiated the contract, the plaintiff should nevertheless be able to assume that the contract remains in force until he chooses to terminate. Once the contract is terminated, it is reasonable that the plaintiff should have to act so far as is reasonable to minimise the defendant's liability, i.e., to mitigate, by recognising that the defendant will not perform and obtaining the benefit the defendant was due to provide from elsewhere, or otherwise minimising the consequences of the defendant's non-performance. But there can be no question of having to mitigate in this way before the acceptance of termination. Under the reliance theory, by contrast, the defendant has not as a rule incurred any duty of performance; instead he has assumed liability for the plaintiff's reliance interest. He may choose not to perform and instead incur liability for the plaintiff's reliance loss, and it follows that he should be able to renounce responsibility for further reliance by withdrawing from the contract. Then the

\footnotetext{
${ }^{41}$ cf Sky Petroleum v VIP Petroleum [1974] 1 WLR 576. See also Freeman \& Mills v Belcher 900 P.2d 669 (Cal 1995), which concerned punitive damages.

${ }^{42}$ As where property has been transferred subject to a restrictive covenant which the defendant is now failing to perform, as in Surrey $v$ Bredero Homes [1993] 3 All ER 705 (where specific performance was denied as oppressive).

${ }^{43}$ Beswick v Beswick [1968] AC 58. The position of third parties is considered below.

${ }^{44}$ See Collins, op cit at n2, 397-98.

${ }^{45}$ The argument for specific performance implies that punitive damages or disgorgement should be available where the defendant deliberately breaches an obligation to perform, i.e., where he knows that damages would be inadequate to compensate the plaintiff for his reliance on the contract. In English law there is a general aversion to supra-compensatory damages (including agreed penalties), but this approach is consistent with the approach of some judges in the US: see in particular the judgment of Mosk J in Freeman \& Mills v Belcher 900 P.2d 669 (Cal 1995). If a contractual relationship is fiduciary, damages are always inadequate, and so disgorgement is the rule.

${ }^{46}$ The most common example of specific performance is said to be the contract to purchase land, and it can be argued that here often the plaintiff has seriously adjusted his position, for example by giving up his house or job or at least that this is the historical basis for the rule: Collins, op cit at n2, 391. But it is doubtful whether it is really plausible to say in all such cases that there is nothing equivalent available.
} 
plaintiff should no longer be able to rely on the contract in the sense of acting on the assumption that the defendant will perform, and any further reliance will be at his own cost; he has no choice but to "accept the breach" and mitigate.

In fact the rule is said to be that the contract continues in force unless the plaintiff "accepts the breach" and agrees to termination; only then does the mitigation rule apply. ${ }^{47}$ This is consistent with the classical theory rather than the reliance theory. But in reality because specific performance is generally unavailable the plaintiff is forced to accept that the defendant will not perform, and he is then expected to mitigate immediately, for example by securing alternative performance, or even taking up an offer from the defendant to perform on revised terms. ${ }^{48}$ This is consistent with the reliance theory and not the classical theory. ${ }^{49}$

The issue of mitigation without "acceptance of breach" arises clearly in the case of anticipatory breach, exemplified by White \& Carter $v$ McGregor.$^{50}$ Here the recipient declares that the contract is over before the supplier has performed or completed performance and before the recipient's performance (payment) is due. The issue is not whether the recipient must accept the supplier's non-performance and mitigate by obtaining the benefit from elsewhere; it is whether the supplier must accept the recipient's declaration that the contract is over and mitigate by ceasing to perform (in circumstances where it is possible for him to continue performing without the recipient's co-operation), or whether he can insist on performing and then recover the contract price from the defendant when it becomes due under the contract. Under the classical theory, it seems that the plaintiff should be able to insist on performing, because the defendant is bound to perform the contract and cannot unilaterally withdraw. But under the reliance theory, provided that the circumstances are not such as to generate a duty of performance, it seems that the defendant should be able to withdraw unilaterally by declaring that the plaintiff may no longer rely on the contract. The decision in White \& Carter $v$ McGregor was that the plaintiff could continue to perform the contract and then claim payment, as one would expect under the classical theory.

\footnotetext{
${ }^{47}$ Howard v Pickforward Tool Co Ltd [1951] 1 KB 417; White \& Carter v McGregor [1962] AC 413.

${ }^{48}$ British Westinghouse Electric v Underground Electric Railways [1912] AC 73; Lazenby Garages Ltd v Wright [1976] 1 WLR 459; D Harris, "Incentives to Perform or Breach Contracts" (1992) 45 CLP 29, 45-6.

49 PS Atiyah "The Liberal Theory of Contract", 124, in Essays on Contract (Clarendon Press, 1986). One can distinguish between two types of mitigation: first where the plaintiff is expected to reduce or avoid increasing the cost of performance; and secondly where the plaintiff is expected to relieve the defendant of performance by procuring an equivalent benefit from elsewhere (or from the defendant). The first type is consistent with the both the classical and the reliance theories, and the second is consistent only with the reliance theory.
}

${ }^{50}$ [1962] AC 413. 
However White \& Carter v McGregor was much criticised and subsequent decisions seem to have retreated from it. ${ }^{51}$ It is inconsistent with the law on specific performance considered above. A plaintiff-recipient is not entitled to hold the defendant-supplier to the contract through an order of specific performance where the continuation of the contract depends on the defendant's performance, and must mitigate once the contract is effectively brought to an end by the defendant's non-performance. Equally, where the plaintiff is the supplier who performs first, he should not be able to hold the defendant-recipient to the contract, and should have to mitigate by ceasing performance himself. It now seems to be accepted, consistently with the reliance theory, that if the defendant-recipient declares that the contract is over the plaintiff-supplier is bound to accept this unless he has a "legitimate interest" in persisting with the contract, ${ }^{52}$ and this may be understood to correspond to the interest that a plaintiffrecipient has in specific performance where damages would be inadequate. That this reflects the understanding and expectations of contractors is supported by empirical work that suggests that in business the cancellation of an agreed order (i.e., withdrawing from an executory contract) is not regarded as wrongful and is not referred to as a "breach of contract". 53

One might object, lastly, that if one party can effectively withdraw unilaterally under the reliance theory, a contract consisting of assumed contingent liabilities is of no legal effect. But this is not so because the other party can recover for reliance incurred before he is notified of withdrawal, and if by this time his reliance interest cannot reasonably be satisfied in money the defendant will have incurred a duty of performance and will not be able to withdraw unilaterally.

\section{ASPECTS OF SUBSTANTIVE LAW}

\section{Inducing a breach of contract}

There has been some controversy over the circumstances in which a third party should incur liability for procuring the breach of a contract. It is surely right that if one person commits a breach of duty another who induces it must also have acted wrongfully, and should also be liable to compensate the person to whom the duty was owed (certainly if he knew that he was inducing a wrong). ${ }^{54}$ Thus the courts have held that a defendant who knowingly induces a contractor not to perform his contract must be liable to

\footnotetext{
${ }^{51}$ Attica Sea Carriers v Ferrostaal Poseiden Bulk Reederei GmbH, The Puerto Buitrago [1976] 1 Lloyd's Rep 250, Clea Shipping Corpn v Bulk Oil International Ltd, The Alaskan Trader [1984] 1 All ER 129; Stocznia Gdanska v Latvian Shipping [1996] 2 Ll Rep 132.

${ }^{52}$ Ibid. The expression comes from Lord Reid's judgment in White \& Carter v McGregor.

${ }^{53}$ Macaulay, op cit at $\mathrm{n} 19,61$.

${ }^{54}$ As a general rule someone who induces or procures a wrong acts wrongfully himself, and there is no reason why the position should be different with respect to inducing or procuring a breach of duty in contract.
} 
the other party to the contract, on the basis that (following the classical theory) one party to a contract has a right against the other to the performance of a contract and the other a correlative duty to perform. ${ }^{55}$ But there has been some hesitation over this liability and also much controversy, and the underlying reason may be the general sense (reflecting the absence of any general right to specific performance) that non-performance is not always wrongful. Under the reliance theory, the tort of inducing breach of contract occurs where the defendant induces a contracting party not to perform the contract in the exceptional circumstances where the contracting party has a duty to perform because of the uncompensable harm that would result from non-performance, but not in the usual case where the contracting party is merely contingently liable for reliance loss. The defendant must know that nonperformance will cause uncompensable harm, so that he will understand that the contract ought to be performed. ${ }^{56}$

\section{Consideration under the reliance theory}

Under the doctrine of consideration in English law, for an agreement to be enforceable it must involve an exchange or bargain by which both parties are to receive a benefit. ${ }^{57}$ This rule is also expressed in the form that a gratuitous promise is unenforceable (unless under seal), but it is only under the classical theory that the two statements are equivalent, since under the reliance theory a contract does not consist of promises but assumptions of responsibility. It would certainly be possible for the law to hold that an assumption of responsibility is unenforceable unless it is made in return for an assumption of responsibility by the other party, or possibly unless it is an assumption of responsibility for reliance incurred in providing a benefit to the person who assumes responsibility. But in fact, although there is no doubt that a gratuitous promise is unenforceable, it is quite clear from the cases that an assumption of responsibility made by agreement but without consideration (in the sense of a bargain or exchange) can indeed be enforceable, and therefore that the requirement of consideration for an enforceable contract is a misapprehension brought about by the mischaracterisation of contract as an exchange of promises.

One type of case where D can be held liable to satisfy P's reliance interest because of an agreement by $\mathrm{D}$ to assume responsibility for it without consideration arises under the doctrine of

\footnotetext{
${ }^{55}$ Lumley v Wagner [1843-60] All ER Rep 208; Torquay Hotel v Cousins [1969] 2 Ch 106.

${ }^{56}$ Where the contractual relationship is fiduciary, inducing or assisting in a breach is always wrongful; here the claim is for "knowing assistance": see Royal Brunei Airlines Sdn Bhd v Tan [1995] 3 All ER 97, 104, where Lord Nicholls referred to "the close analogy" between knowing assistance and inducing a breach of contract. Under the reliance theory a fiduciary relationship is a contractual relationship in which the contract generates a duty from the start because by its nature damages will always be inadequate as a remedy.

${ }^{57}$ But anything requested can be a benefit, even if it accrues to a third party or otherwise would not normally be understood as a benefit to the contracting party; thus sometimes it is said that each party must incur a detriment in providing what the other party has requested.
} 
proprietary estoppel. A typical case is where $\mathrm{D}$ has reached an understanding with $\mathrm{P}$ that $\mathrm{P}$ may rely on D's making a transfer of an interest in land to D, and, if $\mathrm{P}$ has in consequence built on the land in question D is liable to satisfy P's reliance interest, which may require him actually to make the transfer. ${ }^{58}$ The recent developments of promissory estoppel in Australia suggest that whenever the parties have an understanding that P may rely on D's performing in a specified manner, D will be liable to satisfy P's reliance interest without the need for consideration. ${ }^{59}$ There are also various lines of authority concerning the gratuitous provision of services. A long-recognised liability attaches to someone who takes on the management of someone else's business or investments for no consideration. ${ }^{60}$ This liability is considered to arise from the fact that the relationship is fiduciary in character. It is best seen again as arising from an agreed assumption of responsibility. In Hedley Byrne v Heller ${ }^{61}$ a liability for failing to use reasonable care in the provision of gratuitous services was recognised explicitly by reference to the concept of assumption of responsibility. Here it was accepted that a bank could be held liable for the loss incurred in reliance on a credit reference given without due care if in the circumstances it was implicit that the bank had agreed to assume responsibility for such reliance, ${ }^{62}$ to the extent of taking due care in providing the reference. ${ }^{63}$ These are all cases where there is an agreement for no consideration (in the sense that there is no bargain or exchange) by which D assumes responsibility for P's reliance on the

58 Crabb v Arun DC [1976] Ch 179; Taylor Fashions v Liverpool Victoria Trustees [1982] QB 133. PS Atiyah, "Consideration: A Restatement" in Essays on Contract (Oxford, 1996); Collins, op cit at n2, 72. The expectation measure should be awarded when it is reasonably necessary to ensure that the reliance measure is properly satisfied, as considered above.

${ }^{59}$ Walton Stores $v$ Maher (1987-88) 164 CLR 387. See below in the section on variation. Similarly, in the United States under section 90 of the Restatement (Second), a defendant who has made a promise to the plaintiff is held liable to him even though there was no consideration in the sense of a bargain or exchange. See Atiyah, op cit at n58; Collins, op cit at n2, 73. Under section 90, a liability arises where the promisor "should reasonably expect [the promise] to induce [the plaintiff's reliance]", and it would be unjust not to enforce it. Here the promise entails an assumption of responsibility for reliance on it by the promisee.

${ }^{60}$ eg Nocton v Lord Ashburton [1914] AC 392.

${ }^{61}$ [1964] AC 465; there have since been many cases on this point, including Esso v Mardon [1976] 2 All ER 5 and Caparo Industries v Dickman [1990] 2 AC 605.

${ }^{62}$ [1964] AC 465, 529. In this type of case the plaintiff relies on what the defendant has done rather than on the assumption of a specified future performance, and therefore the defendant will normally assume responsibility in relation to a specified form of reliance, e.g. reliance with respect to a specified transaction. There is also a line of cases governing the "common callings", discussed in AJE Jaffey "Contract in Tort's Clothing" (1985) 5 LS 77; Boorman v Brown (1842) 3 QB 511; Midland Bank Trust Co v Hett, Stubbs and Kemp [1979] Ch 384; Esso v Mardon [1976] 2 All ER 5. Cf also the gratuitous service of caring for another's goods, i.e., bailment.

${ }^{63}$ Also there is the case where a claim for payment is awarded to a negotiating party who did work in anticipation of an agreement to carry out a larger work: William Lacey v Davies [1957] 1 WLR 932, Regelian Properties v London Dock Development [1995] 1 WLR 212; J Beatson, The Use and Abuse of Unjust Enrichment (Clarendon Press, 1991), 43. This should be understood as based on an agreement to assume responsibility for reliance during negotiations. The usual understanding is that this is a restitutionary claim based on benefit conferred. But there would be no claim just by virtue of the benefit if there were not an understanding between the parties. The relevance of benefit is that if the defendant will benefit from preparatory work it is fair that he should assume responsibility to pay for it, whereas in other cases the understanding will generally be that the plaintiff bears the risk that preparatory work will be wasted if no contract for the larger work materialises. There may well be consideration (in the sense of exchange) where the defendant benefits from the preparatory work. 
performance explicitly or implicitly agreed. There is no uniform formula for expressing the measure of recovery in these cases, and the issue tends to be controversial. They are generally understood to be concerned with protecting against loss or detrimental reliance. In proprietary estoppel cases, the gist of the cause of action is understood to be detrimental reliance, but the remedy is whatever is necessary to "satisfy the equity", and sometimes specific performance is awarded. ${ }^{64}$ This is consistent with the analysis of remedies above.

The main reason why these types of case have been regarded as non-contractual is of course the bargain or exchange doctrine of consideration. ${ }^{65}$ But this doctrine can only be a contingent or qualifying rule of the law of contract; the essential or defining characteristic is surely that it is concerned with liabilities and duties that arise by virtue of agreement. This interpretation is justified by the moral significance of agreement, and it is surely consistent with English law generally. If an agreement is found to give rise to legal duties and liabilities without consideration, it must be misguided to say that they are non-contractual (or in particular tortious) because they are inconsistent with the exchange doctrine of consideration; in reality it is the case, in relation to that agreement at least, that the doctrine does not apply. ${ }^{66}$ Usually, however, assumptions of responsibility will not arise except as part of an exchange, and the fact that there is an exchange may be the best indicator of an assumption of responsibility. ${ }^{67}$ In the usual case, someone will assume responsibility for reliance loss as the means to acquire a benefit, or payment for a benefit, by way of an exchange. It is possible, however, that one might choose to make an assumption of responsibility for reliance on one's behaviour for other reasons. Possibly one might do this just as a favour. More likely it might happen as part of a relationship in which an assumption of responsibility is part of necessary give and take, even though it is not directly tied to specific behaviour on the part of the other party, as in a proprietary estoppel case between neighbours. Or it might happen where it is incidental to the normal running of a business and will benefit the business through promoting its goodwill, as where a professional person offers gratuitous services to a customer and assumes responsibility for his reliance on them, as in Hedley Byrne. In these types of case, the

\footnotetext{
${ }^{64}$ Crabb v Arun DC [1976] Ch 179; and even a proprietary interest. Similarly under the US section 90 the remedy is what justice requires, and this is sometimes the actual provable reliance loss, but apparently more often the expectation measure: see E Yurio and S Thel, "The promissory basis of section 90" (1991) 101 Yale LJ 111. The expectation measure is clearly recognised in the fiduciary case, where the reliance loss would be very difficult to determine.

${ }^{65}$ The equation of contracting with promising has also obscured the contractual analysis.

${ }^{66}$ That it is really a pretext to describe the liability as tortious is implicit in Lord Devlin's judgment in Hedley Byrne [1964] AC 465 at 525 .

${ }^{67}$ Hedley Byrne [1964] AC 465 at 529, per Lord Devlin. One might say that the assumption of responsibility was intended to give rise to legal relations.
} 
agreement serves as means not for the exchange of benefits but for conferring a benefit in order to assist another in helping himself. ${ }^{68}$

\section{Variation}

The orthodox position is that a contractual variation is enforceable only if it amounts to a new contract satisfying the normal requirements for formation of a contract, i.e., that there is an agreement to vary supported by consideration. A problem has arisen where the contracting parties have agreed on a variation that is unsupported by consideration. The courts have managed to find ways to give effect to such variations. One is through the doctrine of promissory estoppel, which renders enforceable against a contracting party a variation by which he has waived some part of the other's contractual performance. ${ }^{69}$ However, promissory estoppel has not been allowed to give effect to a variation going beyond this and extending performance due or modifying it other than by a waiver of part of it. ${ }^{70}$ Another way is to find consideration moving from a party whose required performance is in reality unchanged in the form (to use the classical terminology) of a promise to perform what was already due under the original contract. $^{71}$

Under the classical theory, there is a duty to perform a contract. It is not inconsistent with this for one party to be able to waive the other's duty or some part of it under the doctrine of promissory estoppel, or even for the law to apply a wider doctrine amounting to abandoning the exchange doctrine of consideration and recognising gratuitous promises as binding. But it is quite inconsistent with the classical theory to hold that a promise to perform in the original terms can satisfy the exchange requirement of consideration, as was recently held in Williams $v$ Roffey. ${ }^{72}$ The only reason why such a promise could amount to a benefit to the promisee is that the original duty was not properly legally enforceable, and although there may be reasons why this is the case, practical or theoretical, it cannot be justified for the law, as it were, to be complicit in recognising its unenforceability. ${ }^{73}$

Under the reliance theory, however, there is generally no duty to perform a contract, and one party is quite entitled to withdraw his performance, subject to a liability for reliance loss. ${ }^{74}$ If the other party wants performance rather than compensation and performance from someone else, he must agree

\footnotetext{
${ }^{68}$ As opposed to gifts or gratuitous promises.

${ }^{69}$ Central London Property Trust v High Trees House [1947] KB 130.

${ }^{70}$ It is said to provide "a shield and not a sword". But see above at n59.

${ }^{71}$ As in Williams $v$ Roffey [1991] 1 QB 1, although this remains controversial.

72 [1991] 1 QB 1.

${ }^{73}$ Cf B Coote "Consideration and Benefit in Fact and in Law" (1990-91) 3 JCL 23.

${ }^{74}$ See the section above on "Withdrawal, termination and mitigation".
} 
to the variation. As discussed above, there is plenty of support for treating a gratuitous assumption of responsibility as binding, and so there is no need for the variation to involve an exchange or bargain. Thus the decision in Williams $v$ Roffey, where the plaintiff agreed to pay the defendant more than originally agreed in order that he would continue to perform a contract of refurbishment, is explicable under the reliance theory but not easily under the classical theory. ${ }^{75}$

Generally, because the reliance theory allows for unilateral withdrawal, it entails a contingent and interactive relationship between the parties, in which the parties have to be prepared to renegotiate rather than insist on performance in the original terms if they do not want to break off relations and go elsewhere. There is some reason to think that this is how contract works in practice. ${ }^{76}$ By contrast the classical theory envisages a relationship involving fixed obligations of performance determined from the start and unalterable without agreement. Thus the reliance theory more readily supports the idea of "relational contracting", in which the terms of a contract are left open and settled or adjusted as the relationship proceeds, and a continuing relationship depends on a willingness to cooperate and to consider the common interest. ${ }^{77}$

\section{Economic duress}

Sometimes (assuming the objection of lack of consideration is overcome) a contracting party will resort to the argument that a variation is unenforceable on the ground that he agreed to it only because other party threatened not to perform the contract in the original terms, and that the threat amounted to economic duress that invalidated the variation. It has been accepted that a threat not to perform a contract can sometimes amount to economic duress that vitiates a variation; until recently, it seems that this was understood to be the case if, first, the defendant's threat to breach was illegitimate, and, secondly, it "overbore the will" of the plaintiff. ${ }^{78}$ The concept of the overborne will is however difficult to apply, because it is extremely implausible that the prospect of non-performance generates greater pressure than many other ordinary commercial situations in which the circumstances force a business into making a contract on unfavourable terms, and such pressure cannot feasibly be regarded as

\footnotetext{
${ }^{75}$ M Chen-Wishart "Consideration: Practical Benefit and the Emperor's New Clothes" in Beatson \& Friedmann, Good Faith and Fault in Contract Law, 123 at 143.

${ }^{76}$ Macaulay describes this as the usual practice in the field of business he looked at: op cit at n19, 61 .

${ }^{77}$ See PS Atiyah, An Introduction to the Law of Contract (Clarendon, 5th ed, 1995), 51. The concept of relational contracting is due to Macneil; see for example IR Macneil "Relational contracting: what we do and do not know" [1985] Wisc LR 483.

${ }^{78}$ Universe Tankships of Monrovia v ITTF per Lord Scarman [1983] AC 366,400. Beatson, op cit, n63, 112; S Smith "Contracting under pressure: a theory of duress" [1997] CLJ 343.
} 
vitiating the consent to contract. ${ }^{79}$ It seems that the crucial question in determining whether the plaintiff's will should be treated as having been overborne has been whether the prospect of not receiving performance left the plaintiff with any real alternative to accepting the variation. ${ }^{80}$ More recently, the House of Lords has adopted the view that there is duress simply where the plaintiff's agreement to the variation was caused by illegitimate pressure; ${ }^{81}$ and it seems on this approach that the plaintiff's absence of an alternative must be relevant to the legitimacy of the pressure.

The law on economic duress is difficult to reconcile with the classical theory. Under the classical theory there is an obligation to perform a contract, and it must always be wrongful to commit a breach of contract and surely therefore also to procure a variation through a threat to breach. Thus under the classical theory it is difficult to see why a variation precipitated by a threat to breach should ever be enforceable. Of course if the defendant merely warned the plaintiff that he might be unable to perform, or sought relief because performance was now unexpectedly onerous, and did not refuse to perform on the original terms, he would not have made a threat or acted illegitimately, but the onus would surely be on the defendant to show this, for example by giving a plausible reason why the plaintiff should have released him from his duty to perform. The lack of any alternative for the plaintiff would not be directly relevant, because under the classical theory the plaintiff is entitled to performance and the defendant is obliged to give it, irrespective of the consequences to the plaintiff. But the reliance theory explains why it can be perfectly legitimate for the defendant to refuse to perform, and how the plaintiff's absence of an alternative is relevant to the legitimacy of non-performance. Under the reliance theory, non-performance is wrongful or illegitimate only when there is a duty to perform because damages are inadequate to satisfy the reliance interest, and only then can a refusal to perform amount to a threat. The absence of any alternative to performance will mean generally that damages are an inadequate remedy, and therefore that the defendant has become subject to a duty of performance. Thus here again the reliance theory explains the substance, if not the language, of the law.

\section{Privity}

The consideration rule must be distinguished from the privity rule. An agreement is designed to alter the normative regime of the parties to it, not other parties. This is so whether it is understood in terms of

\footnotetext{
${ }^{79}$ As the dissenting judges argued in Barton v Armstrong [1975] 2 All ER 465; Lynch v DPP of Northern Ireland [1975] AC 653; Atiyah "Economic Duress and the 'Overborne Will"' (1982) 98 LQR 197.

${ }^{80}$ Pao On v Lau Yiu Long [1980] AC 614, 635 (Lord Scarman); Universe Tankships of Monrovia v ITTF [1983] AC 366,400 (Lord Scarman).

${ }^{81}$ Dimskal Shipping v ITWF [1992] 2 AC 152.
} 
promises $^{82}$ or assumptions of responsibility. Whatever the rationale with respect to promises, it is hardly plausible to conceive of an assumption of responsibility for reliance on one's behaviour that does not take effect by way of communication to the person whose reliance is thereby protected. ${ }^{83}$ Thus the privity rule is a necessary part of the law under both the classical and reliance theories. ${ }^{84}$ The rejection of an exchange doctrine of consideration, which serves to limit the types of promise or assumption of responsibility that are enforceable, does not entail a rejection of the more fundamental doctrine of privity (nor of course does it preclude another form of rule that restricts the circumstances in which a promise or assumption of responsibility is enforceable).

However the privity rule has been subjected to fierce criticism over many years, and recently the Law Commission has put forward a proposal for reform. ${ }^{85}$ The criticism of the privity rule has arisen out of cases where a contract between the plaintiff and the defendant provides that the defendant is to provide performance that will confer a benefit on a third party, and the contract is not fully or adequately performed for the benefit of the third party. The orthodox position seems to be that the third party cannot sue because of the privity rule, and that the plaintiff-contractor can only recover nominal damages because he does not himself suffer loss from the non-performance. ${ }^{86}$ The courts have managed to award substantial damages to the plaintiff-contractor on various bases, but they have not managed to arrive at a solution to deal in terms of principle with the generality of such cases. ${ }^{87}$

But the solution to such problems does not lie in abandoning the privity rule, which is intrinsic to contract law. Even when the purpose of an agreement is to benefit others, it is intended only to alter

\footnotetext{
${ }^{82}$ A promise involves communication to the promisee; this constraint is intrinsic to Raz's definition of a promise, op cit at $\mathrm{n} 1$.

${ }^{83}$ Furthermore, the assumption of responsibility as understood here must involve an understanding or agreement in the sense that the party whose reliance is to be protected must implicitly accept the contractual implied valuation, by which he accepts the risk of loss incurred in reliance beyond the value of the defendant's performance.

${ }^{84}$ The doctrine of privity is inconsistent with the "death of contract" version of the reliance theory which does not regard liability as arising directly from the agreement itself but from reasonable reliance on the other party's behaviour: see the last section below.

${ }^{85}$ Privity of Contract: Contracts for the Benefit of Third Parties, Law Commission Report no 242 (1996). The criticisms and calls for reform are listed at para 2.63. There are many academic articles criticising the privity rule: see for example Flannigan, "Privity - the End of an Era (Error)" (1987) 103 LQR 564; for a different view, see S Smith, "Contracts for the Benefit of Third Parties: Why the Third Party Rule is not the Problem" [1997] OJLS (forthcoming).

${ }^{86}$ Woodar Investments $v$ Wimpey [1980] 1 WLR 277.

${ }^{87}$ One solution is that the plaintiff contracted as agent or trustee for the third party: eg Lloyds v Harper (1880) 16 Ch D 290. But usually the plaintiff will not be acting as agent or trustee but in his own right and on his own behalf. In Jackson v Horizon Holidays [1975] 3 All ER 92, the plaintiff recovered for both his own and his family's loss when a holiday that he had booked failed to meet the contractual specification. And in a line of cases derived from Dunlop v Lambert (1839) $6 \mathrm{Cl} \& \mathrm{~F} 600$, including The Albazero [1977] AC 774, Linden Gardens Trust v Lenesta Sludge Disposals [1994] 1 AC 85, and Darlington BC $v$ Wiltshier Northern Ltd [1995] 1 WLR 68, it has been held that a plaintiff who contracted for work to property can recover the cost of repair even if the property belongs to a third party. In some circumstances the plaintiff may be able to procure specific performance in favour of the third party: Beswick v Beswick [1968] AC 58. But specific performance may not be possible, and, in any case, it would be strange if specific performance were generally available in favour of a third party but not in favour of a contractor himself.
} 
the normative position of the parties to it. The fulfilment of a contract by performance in favour of a third party satisfies the contracting party's reliance interest, not the third party's interest in receiving the performance; and it is right that, unless the plaintiff has assigned the contract to the third party, the plaintiff should be able to waive damages or vary the contract, and so the third party should not generally be able to claim damages from the defendant in his own right. ${ }^{88}$ The shortcomings in the law are not due to the privity rule.

\section{The measure of damages and the derivative right}

Where a contract specifies performance in favour of a third party, under the classical theory there is an obligation to provide the benefit to the third party. If specific performance is not available or not possible, then the plaintiff is entitled to damages. Under the classical theory the plaintiff should be entitled to substantial damages in the amount necessary to simulate performance. Suppose the specified performance is work on the property of the third party; this can be simulated by the award to the plaintiff of the cost of the work, thus enabling him to have the work done by someone else - most feasibly by paying the money over to the third party. Here it is arguable that the money should be received by the plaintiff subject to a trust to be used for the benefit of the third party in completing the work, ${ }^{89}$ on the basis that this will ensure that the payment will not be worth more to the plaintiff than performance now would be worth to him. Under the reliance theory, the plaintiff will be entitled to substantial damages representing the cost of repair or completion, which, so far as the defendant is concerned, he is entitled to keep and do with as he pleases. ${ }^{90}$ This is so because the compensation is not intended to simulate the performance owed to him, but to represent the loss he has incurred by entering the contract, measured, in accordance with the contractual valuation, in terms of the value of the expected benefit. ${ }^{91}$

Sometimes the plaintiff's claim for damages, even substantial damages, will be inadequate to satisfy his reliance interest. Although the plaintiff is free to use the damages as he pleases, if a payment of damages would not enable him to complete the performance due to the third party if he wanted to, his reliance interest would not have been satisfied. In such a case, damages are inadequate to satisfy the reliance measure and specific performance should be available. ${ }^{92}$ This might be the case where the

\footnotetext{
${ }^{88}$ Also, as considered below, contract law determines when liability will be incurred for the reliance of others, and the abandonment of the privity doctrine will tend to subvert this function.

${ }^{89}$ Or at least subject to evidence that he intends to use the money for this purpose.

${ }^{90}$ Subject to any separate contractual arrangement with the third party.

${ }^{91}$ This represents the position reached by Steyn LJ in Darlington BC v Wiltshier Northern Ltd [1995] 1 WLR 68, 80. Lord Griffiths in Linden Gardens [1994] 1 AC 85, 97 preserved a requirement to show that the damages were to be used for the purpose of repair or completion.

${ }^{92}$ Specific performance should in any case be available under the classical theory.
} 
plaintiff sold property to the defendant subject to a restriction on its use in favour of a third party, or possibly where he sold a business to a third party subject to an obligation to pay an annuity out of the profits to a third party ${ }^{93}$ Furthermore there will be cases where even a right of the plaintiff's to compel specific performance will be not be sufficient to secure his reliance interest. In particular, this will be the case where the plaintiff has died. Here, although the plaintiff's estate will have a right of action, this will be inadequate to protect the reliance interest of the dead plaintiff (when he died), because the plaintiff himself will not be there to procure the benefit for the third party if he so wished (on his death) and his estate may not choose to do so - indeed it will be precluded from doing so by the terms of the will or the intestacy rules. Thus here the reliance theory requires that the third party should himself acquire a right to enforce the contract against the defendant in order to ensure that the dead contractor's reliance interest is satisfied. ${ }^{94}$ There is a well established doctrine of equity that establishes exactly this proposition: the doctrine of secret trusts and mutual wills. ${ }^{95}$ Here the defendant has agreed that he will pass on a bequest in the plaintiff's will to a third party. After the plaintiff's death the third party has the right to enforce the contract against the defendant to recover the bequest. ${ }^{96}$ The right of the third party is a "derivative right". It arises entirely from the contract, and its basis is to satisfy the reliance interest of the testator-contractor. It does not presuppose any independent interest of the third party under the contract in the sense of his having a personal interest that would prevail against the right of the testator-contractor (if he were alive) to vary the contract or waive a claim to damages.

This approach also explains the recent case of White $v$ Jones. ${ }^{97}$ Here the defendant solicitor contracted to prepare a will for a client. The will was to include a bequest to the plaintiff, who was of course not a party to the contract between the solicitor and his client. The client died before the will was executed, and it was held that, if the defendant had fulfilled his contract by acting with due diligence, the will would have been executed before the client's death. The House of Lords held that the plaintiff could

\footnotetext{
${ }^{93}$ Beswick v Beswick [1968] AC 58; see above, nn 40-43. Here reliance damages would be a lump sum sufficient to invest for an equivalent annuity. This might be considered inadequate because of the difficulty of valuing the sum or managing it, even if it were possible to extract such a sum from the business.

${ }^{94}$ Beswick v Beswick [1968] AC 58 does not quite illustrate this possibility, because the third party was able to sue in her capacity of executor in the name of the dead contractor.

${ }^{95}$ These cases are of course decided in the language of equity and constructive trusts. The contractual theory suggested here is close to the fraud theory of secret trusts, associated with McCormick $v$ Grogan (1868) LR 4 HL 82: equity lawyers, apparently knowing nothing of contract, regard departing from an agreement as "equitable fraud". Under the doctrine of secret trusts, the third party becomes the beneficiary under a trust of the bequest received by the defendant. I have not discussed the circumstances in which a constructive trust arises in respect of property contracted to be transferred under the equitable doctrine of that "equity regards as done what ought to be done".

${ }^{96}$ One might argue that under the classical theory the plaintiff has a right to performance that passes on his death to his estate, and the decision whether to sue to enforce it now rests with the estate to be exercised to raise money for the estate and not to procure performance for the third party.
}

${ }^{97}$ [1995] 2 AC 207. 
sue in tort for the solicitor's negligence, rejecting the cogent argument that no duty in tort can arise to confer a benefit on a stranger. ${ }^{98}$ But the plaintiff's claim can be more convincingly justified as a derivative right arising purely from the contract to recover the amount of the bequest in order to satisfy the dead testator's reliance interest. ${ }^{99}$

\section{Assumption of responsibility for a third party}

Where A has made a contract for consideration with B by which B is to confer a benefit on C, there is no reason why A should not also be able to make an agreement with $\mathrm{C}$ to assume responsibility for C's reliance on the performance that B has contracted for. There are cases where the court seems to have adopted this analysis. ${ }^{100}$ In such a case $\mathrm{C}$ has a non-derivative personal right to have his own reliance interest protected under his own contract with A; he is not privy to B's contract with A and does not purport to enforce it, although the performance that he relies on is that specified in B's contract. The objection to such an analysis is not absence of privity, but lack of consideration (in the sense of exchange), which as considered above is an objection of doubtful force. It will not of course be easy to say when $\mathrm{A}$ has reached an understanding with the third party $\mathrm{C}$ to assume responsibility for C's reliance on A's performance for B. Generally in such cases agreements will be implied rather than express, and of course objectively interpreted, and it is possible for an agreement to be reached through intermediaries rather than by face-to-face dealing. ${ }^{101}$ In determining when an agreement to assume responsibility has been made, it will be necessary to consider whether $\mathrm{C}$ knows what A's performance for B is and has reason to rely on it, and whether business efficacy requires that A should take responsibility for such reliance. One type of case where it might be plausible is where A by an exemption clause assumes responsibility, as it were, for any liability that $\mathrm{C}$ might incur to $\mathrm{A}$ in tort. ${ }^{102}$ Another possible example is

\footnotetext{
${ }^{98}$ Lord Mustill accepted this argument in his dissenting judgment. See below at $\mathrm{n} 112$.

${ }^{99}$ A number of commentators have suggested some form of contractual solution.

${ }^{100}$ Henderson v Merrett Associates [1994] 3 All ER 506; cf Smith v Bush [1990] 1 AC 831.

${ }^{101}$ AJE Jaffey, The Duty of Care (Dartmouth, 1992), 124, 134.

102 The effect is to confine claims in a complex subcontracting network to contractual claims under the main contracts between adjacent parties in the network, which may well be consistent with the underlying purpose of the network: see Adams \& Brownsword, "Privity and the concept of a network contract" (1990) 10 LS 12; New Zealand Shipping v Satterthwaite (The Eurymedon) [1975] AC 154. But there is a more important basis for protecting the third party C, at least where he is the employee or agent of B, which is to deny that he has a duty other than to B. This was adopted by La Forest J in London Drugs $v$ Kuehne and Nagel (1992) 97 DLR (4th) 261. There is authority for this that appears to have escaped consideration: see Said $v$ Butt [1920] 3 KB 497; P Jaffey, "Contractual obligations of the company in general meeting" (1996) 16 LS 27; cf the cases on ministerial receipt or "payment over" in restitution: see Goff \& Jones, op cit at n25, 750ff.
} 
where $\mathrm{C}$ has appointed B as his fiduciary and B appoints A to carry out the fiduciary functions on his behalf. $^{103}$

\section{CONTRACT AND TORT: A TORTIOUS DUTY IN RESPECT OF RELIANCE LOSS?}

It has been argued above that the Hedley Byrne line of cases should be treated as contractual. The plaintiff is allowed to recover for his reliance loss because of an agreement by the defendant whereby he assumed responsibility for it. But Hedley Byrne is expressed to recognise a tortious duty in respect of economic loss and has been discussed in those terms. A tortious duty would be based not an agreement to assume responsibility, but on criteria relating to the circumstances, like foreseeability, directness or proximity. It is doubtful whether the recognition of such a tortious duty is necessary to explain the cases, but nevertheless the question remains whether there ought to be such a duty, which would give rise to a parallel and sometimes wider liability in addition to or instead of a contractual liability arising from agreement.

The appropriateness of a duty in tort in cases like Hedley Byrne is generally discussed in terms of the desirability of recovery for economic loss in tort (i.e., loss other than injury to the plaintiff or damage to his property). But, although there may be cases concerning economic loss that raise the issue of indeterminacy, it is doubtful whether there is any objection to economic loss as such. Economic loss can be just as serious as property damage, and there are clearly cases where economic loss is recoverable: for example where it is incidental to property damage, ${ }^{104}$ and where it is caused to the plaintiff without his involvement, that is to say, not through his own reliance on the defendant. ${ }^{105}$ What is significant about the loss in the Hedley Byrne line of cases is not that the loss was economic loss, but that it was voluntarily incurred reliance loss, i.e., it was voluntarily incurred by the plaintiff in consequence of his own reliance on the defendant's behaviour.

To allow for recovery for voluntarily incurred reliance loss is (on the reliance theory) the very purpose of contract law. ${ }^{106}$ In contract, a plaintiff recovers for loss that he chose to incur in reliance on the assumption that the defendant would perform (or has performed) in the way specified in the agreement - for example, a loss in the form of money paid, expenditure incurred, or an opportunity

\footnotetext{
${ }^{103}$ It may be that because it is $\mathrm{C}$ who is at particular risk of exploitation by the fiduciary, A will be understood to have assumed responsibility vis-à-vis C as well as B. This may have been the position in Henderson v Merrett Associates [1994] 3 All ER 506.

${ }^{104}$ Spartan Steel \& Alloys v Martin [1972] 3 All ER 557.

${ }^{105}$ Ministry of Housing \& Local Government v Sharpe [1977] 3 All ER 785.

${ }^{106}$ It may be that contractual claims should be confined to this type of loss, and that claims for other types of loss should be treated as arising only in tort, even if there is also a contractual relationship; but this point cannot not be pursued here.
} 
foregone. He chose to incur such a loss as a means to secure the benefit that he contracted for. Such reliance loss is generally pure economic loss. One will not usually choose to incur personal injury or even property damage pursuant to a contract. Usually the plaintiff will also have received a benefit, although not (where the contract has broken down) the whole of the benefit contracted for. He is entitled to recover for his reliance loss to the extent that the benefit does not satisfy his reliance interest, which, as considered above, will generally give him the expectation measure. By contrast, in tort, there has never been recovery for voluntary reliance loss, unless the Hedley Byrne line of cases is so understood. The archetypal torts of assault and trespass do not involve reliance loss at all. In product liability and motor accident cases the plaintiff's loss may have occurred because the plaintiff relied on the defendant's competence, but here the injury is not voluntarily incurred loss; the voluntarily incurred loss is merely the price paid for the product, or an opportunity cost.

The recognition of a tortious claim for voluntarily incurred reliance loss would permit the plaintiff to make a claim for his loss where he had set out to provide a benefit to the defendant, or where he had relied on the defendant to provide a benefit to him, if his reliance satisfied the requisite criteria of foreseeability, proximity or directness, even if he had not made any agreement with the defendant. Even when an agreement had been made, there might on the same basis be a claim to recover reliance loss in tort instead of under the contract, and here recovery would not be limited to the expectation measure in accordance with a contractual valuation, but would require a measurement, independent of the contract, of the plaintiff's reliance loss and the measure of the benefit he received in return. ${ }^{107}$ And this claim might arise even if the contract had been completed and the court determined that the measure of benefit fell short of the reliance loss.

The expansion of the law of tort in this way, with its subversive consequences for the role of agreement in governing liability for voluntary reliance loss, calls for explicit justification. As a general rule, it seems fair to expect someone to take responsibility for a loss he voluntarily chooses to incur in reliance on someone else, a loss that is invariably incurred for the purpose of obtaining a benefit, unless he has first reached an agreement with the person on whom he wishes to rely for that person to assume responsibility for his reliance; and equally it would surely be unfair to inhibit behaviour that is capable of being relied on (including the making of agreements) by the imposition of a liability independent of any assumption of responsibility. If this is right the courts should certainly keep to the test of voluntary

\footnotetext{
${ }^{107}$ i.e., a claim in the restoration or non-contractual quantum meruit, as discussed above.
} 
assumption of liability by agreement for voluntary reliance loss, ${ }^{108}$ even if they are not prepared openly to accept that the liability in the Hedley Byrne type of case is contractual. ${ }^{109}$

There is another line of cases, now discredited, that gave support to a tortious liability in respect of voluntary reliance loss. These are cases where A has agreed by contract with $\mathrm{B}$ to do work that will benefit $\mathrm{C}$, and $\mathrm{C}$, who contracted for the benefit with $\mathrm{B}$ but not $\mathrm{A}$, is allowed a claim in tort against $\mathrm{A}$ in respect of A's work under his contract with B: this was the decision in Junior Books $v$ Veitchi ${ }^{110}$ and Anns $v$ Merton $B C .{ }^{111} \mathrm{C}$ was allowed the cost of bringing the work up to standard, presumably the standard of A's contract with B. In these cases C incurred a loss in paying B for the benefit that A provided, and the most plausible basis for a tortious claim is that it was for this voluntary reliance loss i.e., the amount paid by $\mathrm{C}$ in reliance on the quality of the work done by $\mathrm{A}$, less any benefit received, calculated independently of any contract (i.e., without reference to any contractual valuation). For the reasons considered above, A should not have any tortious duty in respect of such voluntary reliance loss, and it seems that the possibility of such a claim has now rightly been rejected. ${ }^{112}$ The only satisfactory basis for the claim is a derivative right in contract. ${ }^{113}$

\section{THE RELIANCE THEORY BASED ON ASSUMPTION OF RESPONSIBILITY Promises and assumptions of responsibility}

An assumption of responsibility is, like a promise, the result of a voluntary exercise of a normative power. It is for this reason that it falls within the law of contract and not tort. Some might argue that an assumption of responsibility is merely a promise by another name, or a sort of promise. But although one might of course stipulate a usage of the word that encompasses an assumption of responsibility, it seems

\footnotetext{
${ }^{108}$ AJE Jaffey, The Duty of Care (Dartmouth, 1992), 123-4. Although the test of agreement to assume responsibility has been subjected to criticism (e.g. Smith v Bush [1990] 1 AC 831 per Lord Griffiths at 862, K Barker "Unreliable assumptions in the modern law of negligence" (1993) 109 LQR 461), there do not seem to be any cases that cannot be based on it. Conversely, one might argue that a test based on foreseeability, directness or proximity rather than agreement to assume responsibility should have generated liability in a case like Caparo Industries $v$ Dickman [1990] 2 AC 605, where company auditors were held not liable for the reliance loss incurred by shareholders on mistaken accounts.

109 Conversely they should avoid using the expression "assumption of responsibility" where liability is not based on agreement, as Lord Goff did in White v Jones and Spring v Guardian Royal Insurance [1995] 2 AC 296.

${ }^{110}$ [1983] 1 AC 520.

111 [1978] AC 728.

${ }^{112}$ Murphy v Brentwood DC [1991] 1 AC 398. An alternative basis for a claim is that C's loss is the shortfall in a benefit due to him from $\mathrm{A}$, not because this is a means of valuing his reliance loss, but because A owed a duty to $\mathrm{C}$ to confer the benefit, but this is even less plausible; see AJE Jaffey, The Duty of Care (Dartmouth, 1992), 197. Some commentators still curiously treat the shortfall in the benefit as a loss in itself without identifying such a duty, and the point eluded the court in Murphy. In English law there is, as a general rule, no duty to confer a benefit on a stranger, even apparently in the extreme case where the plaintiff is in danger and the defendant is in a position to save him: Dorset v Home Office [1970] AC 1004, 1027.

113 i.e., on the basis that $\mathrm{C}$ will in some circumstances acquire B's accrued right to sue for reliance damages in respect of a defect in A's performance.
} 
that as the concept of a promise is usually understood it is distinct from an assumption of responsibility. A promise to do $\mathrm{X}$ generates an obligation to do $\mathrm{X}$, but an assumption of responsibility in respect of $\mathrm{X}$ does not, unless a further condition relating to the circumstances is satisfied. ${ }^{114}$

The argument in this article does not deny that it is possible to create a moral obligation through a promise - in other words, it does not deny the existence of the normative power of promising - and it does not deny that the law might, or even that it sometimes does, recognise promises that create obligations of performance. The argument is that as a rule contracting parties do not make promises, but exercise a distinct although analogous normative power to assume responsibility for reliance, and that this interpretation of an agreement is consistent with the pattern of remedies and other contract doctrines that are actually found in the law. One might argue that, even if an agreement based on the assumption of responsibility is accepted as a possibility, nevertheless in fact contracting parties make promises not assumptions of responsibility, and the law should be reformed so far as possible to accord with what the classical theory requires, including treating non-performance as a wrong or breach of duty. Whether agreements really entail promising or assumption of responsibility is essentially an empirical question. It depends on the understanding that parties have of what might be called the "normative regime" they create when they contract. One might investigate the question by trying to establish whether contracting parties have a sense that a non-performing party is behaving wrongfully, and whether in failing to provide specific performance or otherwise to respond in accordance with the classical theory the law is failing to give proper effect to what has been agreed. In fact, apart from what one might infer from the established pattern of remedies in the law, there is, as mentioned above, some evidence from empirical research that contracting parties do not regard the classical interpretation as consistent with their agreement: in the usual case they do not understand a contract to create duties of performance, and they do not regard non-performance of a contract as wrongful. ${ }^{115}$

\section{Other types of reliance theory}

\footnotetext{
114 There have been attempts to explain promising by equating a promise with "inducement to incur reliance": N MacCormick, "Voluntary Obligation and Normative Powers I" (1972) Supp Vol 46 Proc of the Aristotelian Soc 59, and in Legal Right and Social Democracy (Clarendon Press, 1982). This seems to be close to the notion of assumption of responsibility, but it is less apt because it seems to suggest that the promisor is manipulating the promisee to secure the reliance rather than making an arrangement with him. Arguably assumptions of responsibility are generally used in a commercial or public context and promising in a social or personal context where the making and keeping of promises reflects and supports a personal relationship and issues of proof of reliance and of remedy are rather beside the point; $\mathrm{c} f \mathrm{~S}$ Smith "Performance, Punishment, and the Nature of Contractual Obligation" (1997) 60 MLR 360.

115 Above n19. Where parties intend to create an obligation, for example because there is uncompensable loss for subjective reasons, one approach would be to use a penalty clause. Such clauses have always been unenforceable in English law however.
} 
The view is sometimes expressed that the classical theory of contract is based on the "will theory", but the reliance theory is not. ${ }^{116}$ The will theory of contract seems sometimes to be taken to be the theory that contract is based on promising, although the expression is more apt to refer to a theory about promising (or about assumption of responsibility), viz., the theory that a promise (or an assumption of responsibility) is binding because it is an exercise of personal autonomy or an expression of the will. The conflation of theories about promising with theories about agreement or contract is unsurprising because promising is taken to be the only means by which it is possible to alter one's normative position by purporting so to do. ${ }^{117}$ By contrast, the reliance theory is sometimes taken not to be based on the will theory, by which is meant that under the reliance theory the law of contract does not give effect to liabilities or obligations voluntarily assumed by agreement, but involves the application of the general law to protect the interests of the parties directly, as in tort or restitution. ${ }^{118}$ On this view it appears that the classical theory, but not the reliance theory, is associated with freedom of contract. But in fact there have been at least three versions of the reliance theory including the one presented here, and only one rejects the view that contract is based on obligations or liabilities voluntarily assumed.

\section{A promise-based version of the reliance theory}

On the first of these two versions of the reliance theory, contract is based on promising, as in the classical theory. Thus a contract is understood to give rise to moral obligations to perform, but these are recognised and enforced in law only if and to the extent that there has been reliance. ${ }^{119}$ Thus here the reliance theory is a theory of consideration, i.e., it provides a criterion of enforceability. ${ }^{120}$ The problem with this approach is to explain why, if the justification for allowing a claim for reliance loss is that the promisor has incurred an obligation on which the promisee is entitled to rely, the obligation should not be fully enforceable as such. ${ }^{121}$ Raz's solution is that to enforce the obligation as such (as opposed to merely compensating for reliance) would be an excessive intrusion by the state into the personal autonomy of an individual. ${ }^{122}$ But one might argue that it respects the autonomy of an individual to hold

\footnotetext{
${ }^{116}$ A Burrows, "The Will Theory of Contract Revived - Fried's 'Contract as Promise”" [1985] CLP 141.

117 i.e., to assume an obligation, as by a promise, or a contingent liability, as by an assumption of responsibility.

118 e.g., Burrows, op cit at n116.

${ }^{119}$ Fuller \& Perdue and Raz, op cit at n2.

${ }^{120}$ PS Atiyah, op cit at n58. Usually on this approach it seems that reliance is a necessary requirement for recovery, whether or not there is also a requirement of bargain or exchange. But Collins seems to regard reliance as an alternative basis for enforcing a promise, instead of exchange or bargain, but not a necessary requirement or constraint: Collins, op cit at n2, 71.

${ }^{121}$ Thus there is some doubt whether the obligation created by the promise is really moral or legal.

122 i.e., a violation of the "harm principle": Raz, op cit at n2, 933-8.
} 
him to an obligation voluntarily created. ${ }^{123}$ At any rate the protection of the reliance interest is more straightforwardly justified by a theory that does not postulate an obligation to perform in the typical case. Also, it is not clear that this version of the reliance theory can explain the various features of contract law that, as demonstrated above, are explained by the theory based on assumption of responsibility. Furthermore, this approach envisages a pervasive shortfall in the legal enforcement of what is understood to be a obligation, which would create a tension in the law between what is agreed and what is enforced, and it is doubtful whether such a tension exists. ${ }^{124}$

\section{The "death of contract" version of the reliance theory}

Under the second version of the reliance theory, as under the assumption of responsibility theory, the law of contract is not understood to create binding obligations of performance, and from this it is inferred that contracts are not based on promises of performance. But in the absence of any other recognised basis for the creation of a voluntary obligation or liability, this has lead to the mistaken conclusion that contract law is not based on the voluntary assumption of obligations or liabilities at all - in other words, that an agreement has no intrinsic legal effect. This is the so-called "death of contract" or "contract as tort" thesis, ${ }^{125}$ under which ostensibly contractual claims are actually a combination of claims in tort for voluntary reliance loss and so-called restitutionary claims for payment for a benefit conferred, both assessed independently of the contractual valuation. The claim is for the non-contractual quantum meruit, or the restoration measure plus a separate claim for payment.$^{126}$

Although this analysis may avoid some difficulties of the classical theory, it is an implausible theory both as a description of the present law and as an ideal, inasmuch as it seeks to eliminate agreement as the basis of contractual liability, or in other words, of liability for voluntarily incurred reliance loss. As considered above, it is surely fair to treat agreement as the basis for such liability - this is the main purpose of agreement - and it would be very difficult to find other criteria that could determine when a defendant should be liable to satisfy the reliance interest of someone who has chosen to rely on him. The death of contract approach would unfairly inhibit behaviour that is capable of being

\footnotetext{
${ }^{123}$ Although particular difficulties arise in cases where specific performance might amount to restraint of trade or even slavery. It also seems that Raz's view would preclude the recognition of covenants and certain types of trust.

${ }^{124}$ See above at $\mathrm{n} 24$.

${ }^{125}$ The expression "death of contract" is associated with Grant Gilmore, The Death of Contract (Ohio State University Press, 1974). Sometimes Atiyah seems to adopt the death of contract theory, but on other occasions he is closer to the version adopted in this article: see particularly PS Atiyah, Promises, Morals, and Law (Oxford, 1981), on "Promises as Admissions".

${ }^{126}$ Above text at $\mathrm{n} 27$.
} 
relied on but should not generate liability for reliance, and also behaviour that should generate such liability but only according to a contractual valuation, including the making of agreements.

However there are certain developments that give some support to the "death of contract" thesis. One is the suggestion that the privity doctrine should be abrogated; this would undermine the role of agreement in determining when there is responsibility for voluntary reliance loss. Other developments appear to recognise the possibility of claims outside contract for voluntary reliance loss and so suggest the recognition of a "death of contract" regime that could intrude into contract. This is the implication of the tortious analysis of Hedley Byrne and of Anns v Merton BC and Junior Books. ${ }^{127}$ There is also the argument that there should be a restitutionary claim on the termination of a contract by breach or frustration, which amounts to a non-contractual quantum meruit, ${ }^{128}$ and there is also some suggestion of a liability for "unjust sacrifice" or non-contractual reliance, for example where a party claims for reliance in advance of making a contract. ${ }^{129}$ Any non-contractual interpretation of these types of claim should be rejected. ${ }^{130}$

\section{The "insuperable difficulty" with reliance theories}

The difficulty that has faced reliance theories is how to reconcile limiting the plaintiff to the recovery of reliance loss with basing the claim on an obligation to perform. What has been described as the "insuperable difficulty" "131 with reliance theories is that if, as under the consideration theory of reliance, the plaintiff's reliance loss is recoverable because it was incurred in reliance on the assumption that an obligation was owed to the plaintiff by the defendant arising from an agreement between them, it is difficult to see why the obligation is not fully recognised and enforced; ${ }^{132}$ and if, on the contrary, there is no such obligation, it is unclear, in the absence of any other basis for giving legal effect to an agreement, how the agreement is relevant to a claim for reliance - hence the retreat by way of the death of contract thesis from the idea that recovery for reliance is based on agreement at all. But the apparently insuperable difficulty arises from the assumption that if agreements are to have any legal effect they must

\footnotetext{
${ }^{127}$ Above, section on Contract and Tort.

${ }^{128}$ Above, text at $\mathrm{n} 27$.

${ }^{129}$ Sabemo Ltd $v$ North Sydney Municipal Council (1977) 2 NSWLR 880; S Stoljar, "Unjust Sacrifice and Unjust Enrichment" (1987) 50 MLR 603; $c f$ above text at n63.

${ }^{130}$ But a statute may in special circumstances override the agreement and allow for the recovery of loss and payment on a basis assessed by the court, as in Pavey \& Matthews v Paul (1986) 162 CLR 221.

${ }^{131}$ Randy E Barnett, "A Consent Theory of Contract” (1986) 86 Colum LR 269,274; see also R Craswell, "Contract Law, Default Rules, and the Philosophy of Promising" (1989) 88 Mich L Rev 489, 498-501; Raz, op cit at n2, 925. As Williston is reported to have said in the proceedings of the American Law Institute in 1926, "Either the promise is binding or it is not. If the promise is binding it has to be enforced as it is made" (quoted in Yorio \& Thel, op cit at n64, 117).

${ }^{132}$ But Raz has offered an explanation of this, as mentioned above; and for another view see S Smith, op cit at n114.
} 
be based on promises and therefore create obligations to perform. The recognition of the assumption of responsibility as the basis of contract resolves the difficulty, because an agreement to assume responsibility can create liabilities to compensate and remunerate without any obligation of performance. Under the reliance theory based on assumption of responsibility it is possible to reject the classical theory whilst preserving the distinct character and role of contract.

\section{Freedom of contract}

Furthermore, unlike the two other versions of the reliance theory considered above, the assumption of responsibility theory does not entail any curtailment of freedom of contract. The first one denies that what was agreed should be fully enforced, and the second one actually denies that an agreement can in itself generate obligations or liabilities. But the assumption of responsibility theory is based on the enforcement of agreements in their own terms, without overriding or disregarding them. Thus the recognition of the assumption of responsibility as the general basis of contract will protect the freedom of contracting parties to make the type of agreement that the reliance theory envisages as typical, and secure it against reform of the law based on the assumption of the classical theory that all agreements create obligations of performance. ${ }^{133}$

\section{CONCLUSION}

In this article the classical theory is understood to be the theory that a contract consists of an agreement whereby each party makes a promise to provide the performance specified in the contract, and incurs an obligation to perform accordingly. Under the version of the reliance theory offered here, an agreement specifies performance for each party without creating any obligation to perform as specified; instead an agreement entails an "assumption of responsibility" by each party, by which he accepts a responsibility to satisfy the other party's reliance interest. A party's reliance interest is satisfied by compensation for loss incurred and payment for work done on the assumption that the other party will perform in the manner specified in the contract. The expectation measure is generally the appropriate measure of damages to satisfy the reliance interest. Under an implicit valuation in the contract a party's potential reliance loss cannot exceed the value to him of the performance specified by the contract for the other party, and because of difficulties of proof it should not generally fall below it. In some cases however the appropriate claim is the lesser measure corresponding to the quantum meruit. The agreement generates a

\footnotetext{
${ }^{133}$ Of course it is often said that the classical theory is characterised by freedom of contract and the reliance theory by constraints on freedom of contract on grounds of fairness: see for example Atiyah, op cit at n77, 7ff. But this important issue is quite separate from what differentiates the two theories as characterised here (although an unfair contract under the classical theory is likely to be more severe because there is an obligation to perform rather than a liability for the reliance interest).
} 
duty to perform the contract only where performance is the only feasible way of satisfying the reliance interest. This characterisation of the reliance and classical theories illuminates a number of controversies in the law of contract, and provides a basis for addressing some important and persistent issues. The reliance theory accounts more convincingly than the classical theory for the main doctrines of contract law, including the general pattern of remedies. The assumption of responsibility version of the reliance theory is not open to the criticisms made of other versions of the reliance theory, and in particular does not entail the rejection of a distinct law of contract based on agreement. 